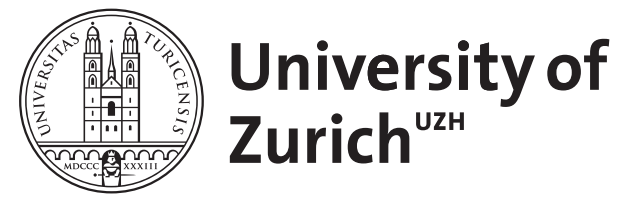
Archive

University of Zurich

University Library

Strickhofstrasse 39

CH-8057 Zurich

www.zora.uzh.ch

Year: 2015

On the natural sciences: an Arabic critical edition and English Translation of Epistles 15-21

Thomann, Johannes

DOI: https://doi.org/10.1093/jis/etu080

Posted at the Zurich Open Repository and Archive, University of Zurich ZORA URL: https://doi.org/10.5167/uzh-102594

Journal Article

Published Version

Originally published at:

Thomann, Johannes (2015). On the natural sciences: an Arabic critical edition and English Translation of Epistles 15-21. Journal of Islamic Studies, 26(1):67-69.

DOI: https://doi.org/10.1093/jis/etu080 
metaphysical standpoints, one needs to engage in spiritual exercises. Since such suggestions-in fact, the very idea that religious thought may fall under the category of 'philosophy'-promise to be controversial, the book does have something connected to the promise of the introduction. Much of that promise, however, remains unrealized.

Anna Akasoy

Hunter College, City University of New York

E-mail:aa739@hunter.cuny.edu

doi:10.1093/jis/etu064

Published online 30 September 2014

\section{On the Natural Sciences: An Arabic Critical Edition and English Translation of EPISTLES 15-21}

Edited and translated by C. BAfFioni (Oxford: Oxford University Press, in association with the Intitute of Ismaili Studies, 2010, 'Epistles of the Brethren of Purity'), xxv +441 pp. (English), 491 pp. (Arabic). Price HB £85.00. EAN 978-0199683802.

In the fourth/tenth century the first encyclopaedias of the sciences in Arabic were written. The terminological handbook Mafätīh al-ulūm ('The Keys of the Sciences') of Muhammad ibn Ahmad al-Khwārizmī (ed. G. Van Vloten, 1895) is a compact but nevertheless comprehensive work. Less known in this context is the Kitäb al-Bad' wa-l-ta'rīkh ('The Book of the Beginning and History') of al-Muțahhar ibn Țāhir al-Maqdisī (ed. C. Huart, 1899-1919), which is not restricted to history but is surveying knowledge in a general way. A research project based at the University of Zurich (2013-2016) and led by James Weaver will provide new findings concerning this neglected work. The collection of the Rasä'il Ikhwān al-Safâa' ('Epistles of the Brethren of Purity') is well known and needs no introduction. Since the pioneering publications of Friedrich Heinrich Dieterici (1821-1903) it formed a pièce de resistance in the history of philosophy. It is most welcome that in a collaborative project based at the Institute of Ismaili Studies in cooperation with Oxford University Press a complete edition and translation in many volumes is being produced. Six volumes have already been published containing Epistles 1-2 (On Arithmetics and Geometry), 5 (On Music), 10-14 (On Logic), 15-21 (On the Natural Sciences), 22 (The Case of the Animals versus Man Before the King of the Jinn), and 52, part 1 (On Magic). The publication of Epistle 4 (On Geography) is planned for 2014.

The volume under review here covers Epistles 15 to 21 on natural sciences, following the part on logic. In content they follow the sequence of Aristotelian books on physics: Physica (15), De caelo (16), De generatione et corruptione (17), and Meterologica (18). After that came books on minerals (19), on general principles of living beings (20) and on plants (21). However, the Epistles are far from being simple compendia of Aristotelian and Peripatetic books. The most striking difference is the aim of the Brethren to provide a Physica Sacra by 
drawing parallels between conceptions of natural philosophy and Qur'ānic passages. The Qur'ān is the most often cited work, in part as single expressions, and in part as longer quotations. Typically such parallels are called expressions of the physicians and philosophers (al-atibbāa wa-l-falāsifa) on one side and the religious law (al-nāmūs) on the other (see p. 272 in the English and p. 335 in the Arabic text). What the former call 'nature' $\left(a l-t a b \bar{i}^{\prime} a\right)$, is called by the latter 'angels' (al-malä'ika). Other differences are scientific conceptions which are absent in the Aristotelian tradition or even contradict Aristotelian views. One class of such differences are astrological doctrines which are ubiquitous in the cosmological parts. Another class are astronomical doctrines which differ considerably from Greek and other Arabic works on astronomy. According to Epistle 16, ch. 22 the heavens consists of 45 spheres, six spheres for each of the seven planets, two for the fixed stars and one for primary motion. This agrees neither with Aristotle nor with Ptolemy, despite the fact that at the end of ch. 22 one is recommended to consult Ptolemy's Almagest for more detailed explanation. Furthermore, the numerical values of the sizes of the spheres do not agree with Ptolemaic values. In Epistle 18 meteorological processes are explained as similar to the practice of the alchemists (așhāb al-șan'a) with their alembics and gourds (see p. 205), and in Epistle 19 sulphur and quicksilver are called the material cause of metals, a doctrine which is not found in the classical tradition and might have had its roots in Indian or Chinese alchemy. This is not the only case in the Epistles in which Eastern sources have to be taken into consideration. The magic squares in Epistle 2 are likely to be descendants of Chinese tradition.

It is an advantage of the series of the 'Epistles of the Brethren of Purity' that each volume is self-contained and can be used without having at hand any other volume of the series. This holds also for the volume under review here. It contains a full description of the manuscripts used for the edition, full bibliography, indices of subjects, of ancient names, of geographical names, of cited texts and of Arabic terms. The translation is distinguished by its clarity without any loss of precision, which makes reading it a pleasure. It is an admirable achievement that C. Baffioni was able to produce this volume of almost one thousand pages only three years after her edition of the logical parts of the Epistles. A core part of the book is the critical edition of the Arabic text with a comprehensive critical apparatus which covers 483 pages. One might wonder how much the text obtained by the critical work differs from the text in previous editions. The șādir edition (Beirut 1957) is the most often quoted edition and its pagination is inserted in the Arabic text and the English translation, but some of its textual variants are only recorded in the last part of the text (see note 45 on p. 327). A test by collating a few pages of Epistle 15 and Epistle 16 in the șādir edition with the critical text has shown that on average 16 variants, omissions or additions are found per page. This must be taken as a severe warning, and it emphasizes the importance of critical editions in Arabic studies.

The book under review here gives not many occasions for criticism. A minor mistake is that the plant name dhurra is translated in its modern sense as 'maize' (see p. 333). This is an anachronism since maize was cultivated in Central 
America and brought by Spanish sailors to the Mediterranean at the beginning of the sixteenth century. Dieterici translated dhurra as 'Negerhirse' (F. Dieterici, Die Naturanschaunng und Naturphilosophie der Araber im zehnten Jahrbundert, Berlin 1861, p. 173), the German name for sorghum (Sorghum bicolor). In classical Arabic pharmacognostic works dhurra (or dhura) was identified as a plant similar to millet (jāwars) and meant very likely the widely cultivated sorghum (see A. Dietrich, Dioscurides Triumphans, Göttingen, 1988, ii. 248). Some identifications of names of minerals might have been improved by checking F. Käs, Die Mineralien in der arabischen Pharmakognosie, (Wiesbaden, 2010). However, these are minor details. The edition of Epistles 15-21 is not to be seen as the end of research on this text, but as a new beginning based on safe textual ground. A large number of scholars within and outside Arabic studies will be grateful for this solid foundation for future work.

Johannes Thomann

Asia-Orient-Institut, Zurich University

E-mail: johannes.thomann@aoi.uzh.ch

doi:10.1093/jis/etu080

Published online 5 November 2014

\section{The Millennial Sovereign: Sacred Kingship and Sainthood in Islam}

By A. Azfar Moin (New York and Chichester: Columbia University Press, 2012), xv + 343 pp. Price HB £38.00. EAN 978-0231160360.

Too seldom does a plodding dissertation become transformed into an elegant monograph. This 2010 dissertation is the rare, and welcome, exception. The Millennial Sovereign surveys a broad range of historical narrative from sixteenth century Mughal India, with frequent, productive references to parallel developments in Safavid Iran. It appears in a series focusing on 'South Asia across the disciplines', the avowed intent of which is to open up new archives and/or show how new methods apply to data from the Indian subcontinent. The author has conducted deep archival research with an accent on visual history and astrology. He demonstrates the intense competition among numerous elites for millennial legitimacy, that is, becoming the single figure who consummates the thousand year stretch of Muslim history, from 622 to $1582 \mathrm{CE}$ or 1 to $1000 \mathrm{AH}$, in South Asia.

At the core of this book's argument are twin themes, highlighted in the subtitle: sacred kingship and (charismatic) sainthood. Both reflect what is variously called 'the spectacle of empire and the theater of sovereignty' (p. 110) or simply 'the theater of empire'. There is ample visual evidence, especially from commissioned paintings at the courts of the Great Mughals (Akbar, Jahangir, and Shah Jahan), which displays the eruption of a post-Timurid, Islamically validated image of the divine sovereign.

Though the book's chronological range is broad, from the fifteenth to the eighteenth centuries, its central thesis hinges on the evidence of four monarchs- 